\title{
Graduates’ Voices on Principal Preparation
}

\author{
Rosalinda Hernandez (Corresponding author) \\ College of Education, The University of Texas Pan American \\ 1201 West University Dr., Edinburg, TX 78539, United States \\ Tel: 1-956-665-3436_E-mail: rhernandez51@utpa.edu
}

Maria B. Roberts, Ed. D.

College of Education, The University of Texas Pan American

1201 West University Dr., Edinburg, TX 78539, United States

Tel: 1-956-665-3436_E-mail: mbroberts@utpa.edu

Received: October 1, 2012 Accepted: October 20, 2012 Published: November 1, 2012

doi:10.5296/jse.v2i4.2489 URL: http://dx.doi.org/10.5296/jse.v2i4.2489

\begin{abstract}
This study describes one university's results of graduates' perceptions of principal preparation and its nature and significance related to the three domains of community, instructional and administrative leadership of a certification examination. Using frequency response rates, the results indicated that in all three domains the leadership preparation program received low satisfaction ratings in the strongly agree category and high percentages in the disagree category of satisfaction. Cross tabulation with the demographic variables indicated a weak or no relationship to the responses of the individual survey items. The findings were used as a component of the process in redesigning a university's leadership preparation program.
\end{abstract}

Keywords: Leadership, Perceptions of graduates, Higher education, Hispanic students 


\section{Introduction}

The accountability requirements, both at the state and national level, with the No Child Left Behind legislation, place tremendous pressure on principals to improve student achievement in the schools. Because of this great emphasis on continuous increase of student achievement and school improvement, there is much debate whether leadership preparation programs have stayed abreast of the changing demands of the field. Several studies have documented the resulting lack of preparedness (Archer, 2005; Azzam, 2005; Hess \& Kelly, 2005a). In a 2003 survey, $67 \%$ of the principals revealed that leadership training in schools of education did not prepare them for their role as instructional leaders (Farkas, Johnson \& Duffett, 2003). Again in 2007, 69\% of the principals shared the same sentiment (Darling-Hammond, LaPointe, Meyerson, \& Orr, 2007). To add to the discourse, a 2006 survey by Public Agenda, a nonprofit research organization that reports public opinion and public policy issues, found that nearly two-thirds of principals felt that typical graduate leadership programs "are out of touch" with today's realities. Principal preparation programs place too much emphasize on lectures and theory and not enough on application (Martin \& Papa, 2008). The Southern Regional Education Board (2005) states that, "traditional models of training principals are still out of sync with the challenges faced by today's leaders” (p. 3).

The role of the principal has also developed into one of an instructional leader (DiPaola \& Hoy, 2008; Marzano, Waters, \& McNulty, 2005) with more emphasis in the areas of instruction, curriculum, assessment, data analysis, and data-driven decision-making. Leading public schools requires that principals become instructional leaders to meet the demand of increased student achievement. As the accountability movement gained momentum, the role of the principal changed from school manager to school instructional leader and then to school reform leader. With this shift in role focus, principals have retained their management roles and currently play multiple roles: school manager, instructional leader, and the leader of school reform.

Furthermore, in an era of shared decision-making and site-based management, the principal is responsible for the overall operation of a school. As managers, principals are responsible for financial operations, building maintenance, student scheduling, personnel, public relations, school policy regarding discipline, coordination of the instructional program, and other overall school matters. With so many skills needed to improve schools and instruction, some entities, such as the state of Texas, developed assessments of certification standards school leaders must master to practice their profession in public schools.

\section{Domains of the Texas Standards}

The Texas Examination for Educator Standards (TExES) is a comprehensive criterion-referenced test based on areas of leadership known as domains. The three domains in the principal framework consist of school-community leadership (33\%), instructional leadership (45\%), and administrative leadership (22\%). Each domain consists of competencies and those competencies are further divided into descriptive statements specific to each competency. Domain I contains three competencies with 29 descriptive statements; Domain II contains four competencies with 31 descriptive statements, and Domain III contains two 
competencies with ten descriptive statements. Forty-four percent of these Texas standards for principal certification are in the area of instructional leadership, reflecting the importance of this component for principals (Texas Education Agency, 2010). Texas is also one of 43 states where the Interstate School Leaders Licensure Consortium (ISLLC) standards served as a guide for creating the principal standards and competencies for certification (Derrington \& Sharratt, 2008).

\subsection{Domain I. School Community Leadership}

Site-Based Decision Making is federally mandated legislation requiring that all stakeholders' of the school systems be included in the school's decision-making. As the stakeholders voice their interests and goals for public institutions, the school leader is the main advocate and role model reflecting the collaborative and inclusive culture of the school. School leaders must have the personal skills to recognize the shared ownership of the school and to develop relationships that will help to meet the students' learning goals (Ferrandino, 2001; Moore, Gallagher, \& Bagin, 2010). Whether it is at parent-teacher conferences, at school board meetings, or when coming across parents at the grocery store, the school leader must be prepared to offer a positive picture of the school and its environment. With the advent of charter schools competing for public school students, the survival and reputation of a school are dependent on that positive image portrayed by the school (Drake \& Roe, 2003; Ferrandino, 2001; Moore, Gallagher, \& Bagin, 2010). The importance of building community relationships is reflected in the two competencies and descriptive statements of Domain I.

\subsection{Domain II. Instructional Leadership}

Hoy a \& Hoy (2006) state that the primary goals of school are teaching and learning. School leaders must be knowledgeable of effective teaching methods for special students groups which may be neglected in the present system (United States Department of Education, 1999). It is known that instructional leaders are known to be adept in various other responsibilities, such as establishing and communicating the vision and goals of the school (Harris, 2007; Marzano, Waters, \& McNulty, 2005) and ensuring meaningful professional development of teachers (Glickman, 2005; Marzano, et al., 2005). Finally, school leaders must be able to distribute leadership roles among faculty to form an instructional leadership team which will multiply the assistance provided to teachers (Zepeda, 2007). All these skills are encompassed in the four competencies and descriptive statements of Domain II.

\subsection{Domain III. Administrative Leadership}

Among the various responsibilities a school leader inherits are budgeting funds, administering special programs, recommending the hiring and dismissal of faculty, maintaining and using the facility for optimal efficiency, scheduling, and reporting (Kaiser, 1996). Although these activities do not appear to be instructionally related, student success, student comfort, and community support depend on the effective practice of these duties. In addition, leaders must be skillful in these areas to avoid legal problems with special population programs and funding. Domain III includes two competencies and the corresponding descriptive statements which are tested in this area. 


\section{Macrothink}

Journal of Studies in Education

ISSN 2162-6952

2012, Vol. 2, No. 4

Figure 1 depicts the three domains for certification of Texas school leaders and the corresponding weights on the examination.

\section{Composition of TExES Exam}

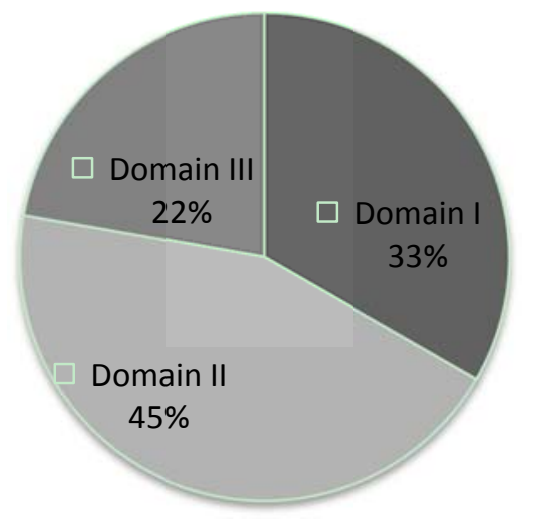

Domain I: Community Leadership

Domain II: Instructional Leadership

Domain III: Administrative Leadership

Figure 1. Percentage composition of Texas Examination for Educator Standards for Texas school leaders. Texas Education Agency, 2010

The Texas State Board for Educator Certification (SBEC) compiles all the results of the exams and reports the passing rates to higher education institutions. The standard for an institution to remain accredited is currently $80 \%$. Therefore, university principal preparation programs have a need to align the curriculum to all the domains and competencies. With this in mind, the purpose of the study was to obtain graduate perceptions of principal preparation from one university and its nature and significance related to the three domains of community, instructional and administrative leadership of a certification examination.

\section{Methods and Procedures}

\subsection{Methodology}

To obtain data from the graduates, the researchers developed a survey of twenty-one questions based on state standards and competencies for principal preparation. After developing the survey, it was field-tested with a group of post-graduate students to ensure validity. An open-ended question was added to the survey after the field test to allow the participants to add any comments they deemed important for their principal preparation.

\subsection{Participants}

The population of study was all graduates of the principal preparation program for the past three years. Student e-mail addresses were obtained through the registrar's office. The

survey was sent to all 315 students on the list and approximately one third of the students responded. Eleven entries from the survey results were deleted due to non-response of any items. Of the total remaining respondents 71 were female, 24 were male, 26 were 
administrators, and 59 were teachers. A frequency distribution of the ordinal responses was compiled.

\subsection{Survey Analysis}

The survey used a four point Likert scale ranging from Strongly agree to Strongly Disagree to indicate the quality of principal preparation. Frequency distributions were tabulated per item and per domain. A cross tabulation analysis was conducted to determine if there were differences in the responses between gender, job role, years of experience as administrator, years of experience as a teacher, ethnicity, and years in the district.

\section{Results}

The program under study is located in the state of Texas in the United States. This state requires potential administrators to pass a certification examination. The test is called the Texas Examinations of Educator Standards (TExES). Passing this examination is a prerequisite for employment as a public school administrator. Just as future administrators feel pressured to pass the state exam, universities offering principal preparation programs, also, have tremendous pressure to ensure their graduates pass this state exam. Principal preparation programs strive to align their curriculum to these competencies and descriptive statements for each competency.

In an effort to determine the level of preparation of graduates of the current principal preparation program at a university, the researchers surveyed their program graduates with questions aligned to the three domains of the state standards. The researchers categorized the responses into four categories: Strongly Agree, Agree, Disagree, and Strongly Disagree. High percentages in the Strongly Agree category would indicate robust student satisfaction with the level of preparation in the three domains. Agree responses were interpreted as marginal satisfaction with the preparation program. Disagree and Strongly Disagree responses would convey dissatisfaction with the level of preparation in the three domains.

\subsection{Frequency Distributions}

Tables 1-3 detail the results of the survey responses per item and per domain. The results indicate a wide discrepancy in student opinions regarding how well the competencies were addressed by the program as indicated by the Likert scale of Strongly Agree, Agree, Disagree, and Strongly Disagree. Of the 21 survey items, data indicating satisfaction with the program was conveyed through the "Strongly Agree" responses, which ranged between 34\% and 68\%. The "Agree” category responses, which also indicated some satisfaction with the program, ranged between $23 \%$ and $41 \%$. Dissatisfaction with the program was confirmed through the "Strongly Disagree" responses, which ranged from 3\% to 7\%, and through the "Disagree" responses, which ranged from $1 \%$ to $21 \%$. The highest means in Domain I, School Community Leadership and Domain II, Instructional Leadership, were in the categories of Strongly Agree with means of 56\% and 52\% respectively. Domain III, Administrative Leadership, resulted with a means of $40 \%$ for both Strongly Agree and Agree. 
Table 1. Domain I Results

\begin{tabular}{lllll}
\hline Domain and Competency Description & $\begin{array}{l}\% \text { Strongly } \\
\text { Agree }\end{array}$ & \% Agree & $\begin{array}{l}\% \\
\text { Disagree }\end{array}$ & $\begin{array}{c}\text { \% Strongly } \\
\text { Disagree }\end{array}$ \\
\hline $\begin{array}{l}\text { DOMAIN I: } \quad \text { School Community } \\
\text { Leadership }\end{array}$ & 63 & 30 & 1 & 7 \\
Ethical Behavior & 68 & 23 & 3 & 6 \\
Advocate for Children & 60 & 31 & 2 & 6 \\
Understands Community Culture & 56 & 32 & 5 & 6 \\
Confident of Soft Skills & 55 & 34 & 5 & 6 \\
Verbal Communication Skills & 54 & 29 & 9 & 7 \\
Written Communication Skills & 47 & 39 & 10 & 4 \\
Public School Law & 52 & 33 & 12 & 3 \\
Innovative Thinker & 50 & 31 & 17 & 3 \\
TExES Preparation & $56 \%$ & $29 \%$ & $7 \%$ & $6 \%$ \\
\hline Domain I Mean & & & & \\
\hline
\end{tabular}

Percent frequency distributions indicating to what degree graduates felt the principal preparation program prepared them in the given state assessment domains and competencies $(n=864)$.

Table 2. Domain II Results

\begin{tabular}{llllll}
\hline Domain and Competency Description & $\begin{array}{l}\% \\
\text { Agree }\end{array}$ & Strongly & $\begin{array}{l}\% \text { Agree } \\
\text { Dis }\end{array}$ & $\begin{array}{l}\% \\
\text { Disagree }\end{array}$ & $\begin{array}{l}\% \\
\text { Disagree }\end{array}$ \\
\hline $\begin{array}{l}\text { DOMAIN Instructional } \\
\text { Leadership }\end{array}$ & & & & \\
Data-Driven Decision Maker & 53 & 31 & 9 & 6 \\
Campus Improvement Planning & 49 & 32 & 13 & 6 \\
Research and Best Practices & 65 & 30 & 7 & 6 \\
Staff Development & 65 & 33 & 6 & 6 \\
Curriculum \& Instruction Leader & 50 & 39 & 4 & 7 \\
Hire, Staff, \& Evaluate Personnel & 51 & 33 & 12 & 4 \\
Advanced Technology Skills & 46 & 35 & 14 & 5 \\
Student Code of Conduct & 50 & 31 & 17 & 3 \\
\hline Domain II Mean & $51 \%$ & $33 \%$ & $10 \%$ & $6 \%$ \\
\hline
\end{tabular}


Table 3. Domain III Results

\begin{tabular}{lllllll}
\hline Domain and Competency Description & $\begin{array}{l}\% \\
\text { Agree }\end{array}$ & $\begin{array}{l}\text { Strongly } \\
\end{array}$ & $\begin{array}{l}\% \\
\text { Agree }\end{array}$ & $\begin{array}{l}\% \\
\text { Disagree }\end{array}$ & $\begin{array}{l}\% \\
\text { Disagree }\end{array}$ \\
\hline DOMAIN III: Administrative & & & & & \\
Leadership & & & & & \\
State \& Federal Accountability & 46 & 41 & 9 & 4 & \\
School Safety \& Crisis Management & 43 & 39 & 14 & 3 \\
Management of Physical Plant & 35 & 40 & 21 & 4 \\
School Budgeting & 34 & 40 & 20 & 7 & \\
\hline
\end{tabular}

Percent frequency distributions indicating to what degree graduates felt the principal preparation program prepared them in the given state assessment domains and competencies $(\mathrm{n}=384)$.

\subsection{Cross tabulation}

In addition to the percent frequency distributions, a cross tabulation of participant demographics as variables was conducted on the item responses. The demographics included ethnicity, gender, years as administrator, years as teacher, and years in district. The levels of correlation were based on lambda. The correlation results between ethnicity and all items ranged from .02 to .06 between gender and all items from .00 to .16, between job role and all items from .00 to .22, between years as administrator and all items from .02 to .08, between years as teacher and all items from .00 to .13, and between years in district and all items from .00 to .27. Based on the lambda results, all five demographic variables showed a weak or negligible relationship to the responses given to the survey items.

\section{Discussion}

Kersten, Trybus, and White (2009) suggest aligning program content to standards. Such standards may be derived from state or organizational policy. The resulting data in this study indicated non-alignment with the TExES certification standards for principals based on graduate perceptions. Data from the survey indicates a high percentage of combined Strongly Agree and Agree responses. The researchers proposed an $80 \%$ response rate in the Strongly Agree category to indicate strong program effectiveness. Based on the $80 \%$ expectation, none of the domains or individual items met the proposed standard. The highest scoring domain in the Strongly Agree responses was Domain I with a mean of 56\%. Domain II, followed with a $51 \%$ overall rating, and Domain III, was last, with an overall $40 \%$ mean in Strongly Agree.

Data also indicated that there was dissatisfaction in all three domains as evidenced within the Disagree and Strongly Disagree categories. Researchers proposed $10 \%$ or less as acceptable in these combined domains. None of the domains achieved $10 \%$ or less of the desired researchers' standard.

\section{Recommendations and Conclusions}

The purpose of this study was to garner the opinion of program graduates for the past three years to determine their satisfaction with the level of preparation in the three domains of the 
state assessment. The growing body of empirical evidence demonstrates that the quality of leadership provided by school and district leaders is highly dependent on the quality of their preparation experiences (Baker, Orr, \& Young, 2007). Baker, Orr, and Young (2007) ascertain that the multitude of preparation programs currently available have no means of evaluating how well they are accomplishing their goals due to the lack of data and support for program improvement. Therefore, faculty of principal preparation programs must determine whether they are producing quality leaders and whether their preparation program is meeting the needs of its graduate students, while also meeting state certification requirements.

Consideration of the findings suggests the following recommendations for universities to consider in improving principal preparation programs.

1. A program evaluation of the principal preparation program should be conducted to determine alignment of courses to the state or national standards.

2. A program evaluation should include the opinions of graduates regarding their satisfaction with the preparation program.

3. Further studies should be conducted to determine correlation between the results of the state exams and the graduates' perceptions of their principal preparation.

4. Follow-up studies should be conducted every 2-3 years in order to monitor the perceptions of the program graduates, alignment to standards, and graduate success on the state exam.

Although the purpose of principal preparation programs is to prepare students to function successfully in their chosen careers as school principals, this objective may not be reached by all students. Students, who are not adequately prepared for this career, represent the failure of the preparation program to provide the knowledge, skills, and competencies needed to successfully fulfill their role as a practicing principal. This study proved to be invaluable to the educational leadership department by revealing gaps in the program's curriculum. The findings of the study forced department faculty to re-imagine and restructure the way in which it develops school principals in collaboration with graduates.

\section{References}

Archer, J. (2005). Study blasts leadership programs. Education Week, 24(27), 1-18.

Azzam, A. (2005). The unprepared administrator. Educational Leadership, 62(8), 88-89.

Baker, B., Orr, M. T., \& Young, M. D. (2007). Academic drift, institutional production and professional distribution of graduate degrees in educational administration. Educational Administration Quarterly, 43(5). http://dx.doi.org/10.1177/0013161X07303320

Darling-Hammond, L., LaPointe, M., Meyerson, D., Orr, M., \& Cohen, C. (2007). Preparing school leaders for a changing world: Lessons from exemplary leadership development programs. Stanford, CA: Stanford University, Stanford Educational Leadership Institute.

Derrington, M.L. \& Sharratt, G. (2008). Evaluation of principals using Interstate School Leaders Licensure Consortium (ISLLC) Standards. Journal of Scholarship \& Practice, 5(3), 
20-29.

Drake, T. L. \& Roe, W. H. (2010). The principalship. Upper Saddle River, NJ: Pearson Education, Inc.

DiPaola, M. F. \& Hoy, W. F. (2008). Principals improving instruction: Supervision, evaluation, and professional development. Boston, MA: Pearson Education, Inc.

Farkas, S., Johnson, J., \& Duffett, A. (2003). Rolling up their sleeves: Superintendents and principals talk about what's needed to fix public schools. New York: Public Agenda.

Ferrandino, V. L. (February 2001). Challenges for $21^{\text {st }}$ entury elementary school principals. Phi Delta Kappan, 82(6), 440-442.

Glickman, C. D. (2005). Leadership for learning: How to help teachers succeed. Alexandria, VA: Association for Supervision and Curriculum.

Harris, A. (2007). Distributed leadership: Conceptual confusion and empirical reticence. International Journal of Leadership in Education, 10(3), 1-11. http://dx.doi.org/10.1080/13603120701257313

Hess, F. M., \& Kelly, A. P. (2005a). The accidental principal: What doesn't get taught in educational leadership schools? Education Next, 5(3), 34-40.

Hoy, A. W, \& How, W. K. (2006). Instructional leadership: A research-based guide to learningin schools ( $2^{\text {nd }}$ ed.). Boston, MA: Allyn \& Bacon.

Kaiser, J. S. (1996). The $21^{\text {st }}$ century principal. Mequon, WI: Stylex Publishing Company.

Kersten, T., Trybus, M., \& White, D. (2009). Improving administrative internship programs: Perceptions of Illinois principals. [Online] Available: http://cnx.org/content/m23291/1.1

Martin, G.E., \& Papa, R. (2008). Examining the principal preparation and practice gap. Principal, 88(1), 12-14.

Marzano, R. J., Waters, T., \& McNulty, B. A. (2005). School leadership that works: From research to results. Alexandria, VA: Association of Curriculum and Supervision Development.

Moore, E. H., Gallagher, D. R., \& Bagin, D. (2010). The school and community relations. Upper Saddle River, NJ: Pearson Education, Inc.

Southern Regional Education Board. (2005). SREB's leadership curriculum modules engage leaders in solving real school problems. Alanta, GA: Author. [Online] Available: http://www.nde.state.ne.us/hstw/brochures/Engaging Leaders.pdf

Texas Education Agency. (2010). TExES preparation manual: Principal. Austin, TX:Educational Testing Service.

U.S. Department of Education. (1999). Perspectives on education policy research-Policy brief: Effective leaders for today's schools: Synthesis of a policy forum on educational 


\section{Macrothink}

Journal of Studies in Education

ISSN 2162-6952 2012, Vol. 2, No. 4

leadership. Jessup, MD: U.S. Department of Education, Education Publications Center: Author.

Zepeda, S. J. (2007). The principal as instructional leader: A handbook for supervisors (2 ${ }^{\text {nd }}$ edition). Larchmont, NY: Eye on Education.

\section{Copyright Disclaimer}

Copyright reserved by the author(s).

This article is an open-access article distributed under the terms and conditions of the Creative Commons Attribution license (http://creativecommons.org/licenses/by/3.0/). 